\title{
Benthic Foraminifera of the Agulhas Bank coastal shelf in the vicinity of Plettenberg Bay, South Africa: a reconnaissance survey
}

\author{
Susanne Hempel ${ }^{1} \cdot$ Burg Flemming $^{2}$ (1) \\ Received: 18 December 2020 / Accepted: 14 March 2021 / Published online: 16 April 2021 \\ (C) The Author(s) 2021
}

\begin{abstract}
The study area is located on the inner Agulhas Bank around Plettenberg Bay, southern Cape Province, South Africa (Fig. 1). The Agulhas Bank is a transitional environment between the cold-temperate Benguela Current regime of the south-eastern South Atlantic and the warm-temperate Agulhas Current regime of the south-western Indian Ocean. Three distinct faunal assemblages (A, B and C) were identified in the study area. These are aligned in three consecutive, coast-parallel belts, assemblage A forming the inshore belt, assemblage $\mathrm{C}$ the offshore belt and assemblage $\mathrm{B}$ the in-between belt. Assemblage $\mathrm{A}$ is composed of Textulariagroup individuals and Pararotalia sp., Cibicides lobatulus and Planorbulina mediterranensis. It occupies the nearshore belt up to $50 \mathrm{~m}$ water depth in sediments composed of very fine, fine and medium sands, with some coarse and very coarse sands. Assemblage B is composed of Bolivina cf. pseudopunctata, Cassidulina laevigata, Ammonia beccarii, Bolivina tortuosa and Bulimina elongata. It occupies water depths from 50-70 m, but may locally extend down to $90 \mathrm{~m}$ and, within the bay itself, upward to $20 \mathrm{~m}$ in fine and very fine sands containing some medium sand and mud. Assemblage $\mathrm{C}$ is dominated by Cassidulina laevigata, Bolivina cf. pseudopunctata, Bulimina elongata and Ammonia beccarii. In contrast to assemblage B which is dominated by $B$. cf. pseudopunctata, assemblage $\mathrm{C}$ is dominated by $C$. laevigata. Assemblage $\mathrm{C}$ is mainly confined to water depths of $70-100 \mathrm{~m}$ in sediments dominated by very fine sand $(0.063-0.125 \mathrm{~mm})$ containing some coarser sediment and mud. The distribution of the forams with respect to water depth, sediment composition and other environmental parameters suggests that it is mainly controlled by a combination of environmental parameters. No tangible relationship was found between the open shelf foraminifer communities and those of estuaries and lagoons along the South African coast.
\end{abstract}

\section{Introduction}

The earliest study of benthic Foraminifera (forams) from the South African shelf was carried out by Brady (1881), who analysed two samples collected in the course of the famous 'Challenger Expedition' (1872-1876). This was followed by the foram study of Heron-Allen and Earland (1915) on the Kerimba Archipelago off the coast of Mozambique. After a lengthy pause, foram studies eventually recommenced from the early 1970 s onward. Only 10 years ago Toefy (2010) remarked that foram research in South Africa has largely been

This article is part of the Topical Collection on Coastal and marine geology in Southern Africa: alluvial to abyssal and everything in between.

Burg Flemming

Kiel, Germany

2 Wilhelmshaven, Germany conducted in geological contexts (Martin 1974, 1981; McMillan 1974, 1987, 1993; Cooper and McMillan 1987; Wright et al. 1990; Franceschini et al. 2005) and that with few exceptions (Toefy et al. 2003, 2005), studies on extant taxa were largely missing. This disparity has not changed very much since then, the few studies that were conducted mainly focussing on shallow water, salt marsh and mangrove environments (Schmidt-Sinns 2008; Strachan et al. 2015, 2016, 2017; Fürstenberg et al. 2017).

The present study is located on the inner Agulhas Bank, in and around the Plettenberg Bay region, southern Cape Province, South Africa (Fig. 1). The Agulhas Bank occupies a transitional position between the cold-temperate upwelling regime (Benguela Current) of the south-eastern South Atlantic and the warm-temperate Agulhas Current regime of the southwestern Indian Ocean (e.g. Dingle and Rogers 1972; Cawthra et al. 2020). The south coast is known for a diverse marine fauna that is exceptionally rich in endemic species (e.g. Branch and Branch 1981; Griffiths et al. 2010; Smit et al. 2017). Of relevance to the present study could be the 


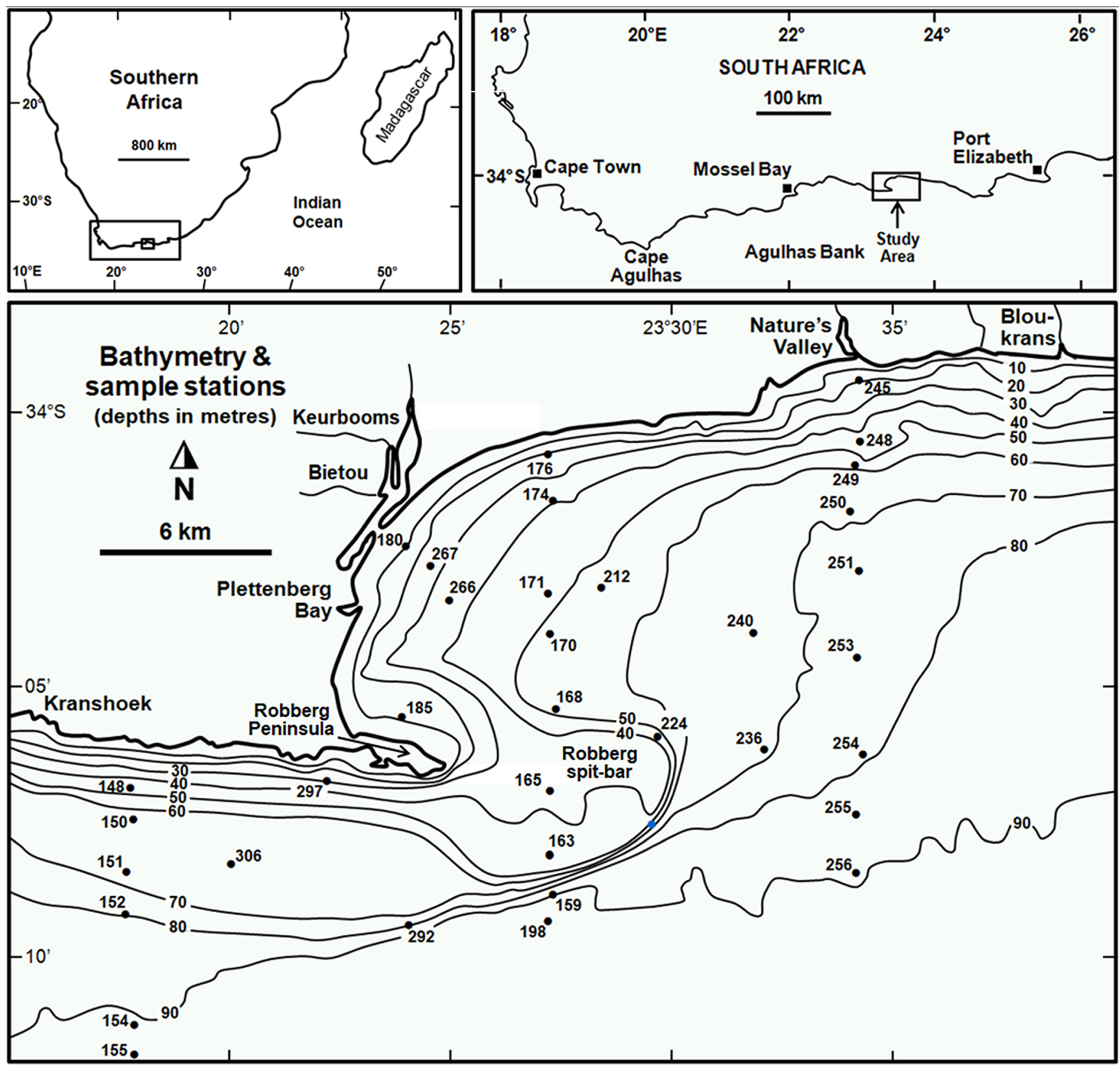

Fig. 1 Geographic location of the study area off Plettenberg Bay (Agulhas Bank, South Africa) showing the bathymetry and sample locations

investigation of Strachan et al. (2016) who, amongst others, analysed the foram community in the Knysna Lagoon, which is located only $30 \mathrm{~km}$ to the west of Plettenberg Bay.

In the context of the situation outlined above, the focus of this reconnaissance survey is on the documentation of the dominant foram species in a spatially confined region along the south coast of South Africa. It is based on a hitherto unpublished dataset (Hempel 1985) and does specifically not aim at documenting every single species, irrespective of how infrequent it may be. Accordingly, the aims of the present study are (a) to document the dominant benthic Foraminifera of the study area, (b) to analyse the data for the existence of spatially defined faunal assemblages, (c) to investigate potential relationships between faunal communities and environmental factors and d) to compare the open coast community with the one in the nearby Knysna Lagoon.

\section{Materials and methods}

The study is based on altogether 35 sediment samples (Fig. 1) selected from a larger sample suite (Flemming, unpublished) collected in March 1982 in the course of the Agulhas Bank Studies programme of the former National Research Institute for Oceanology (CSIR), Stellenbosch, South Africa (cf. Schumann et al. 1982). The area over which the samples were 
distributed covers $\sim 280 \mathrm{~km}^{2}$ which, on average, amounts to 8 samples per $\mathrm{km}^{2}$. Sampling made use of a Shipek ${ }^{\mathrm{TM}}$ grab sampler that was deployed in water depths from $12-97.5 \mathrm{~m}$ (Table 1) in sediments ranging from muddy very fine sand to coarse sand. The rotating steel bucket of the grab scoops up an almost undisturbed sample from the seabed. The typical surface area of a sample in the bucket is $\sim 300 \mathrm{~cm}^{2}$ and the volume $2-2.5 \mathrm{dm}^{3}$ (or litres). The centre section is up to $10 \mathrm{~cm}$ deep, pinching out towards the two bucket edges aligned perpendicular to the direction of rotation.

For the purpose of analysing the foram content, 5 up to $2-\mathrm{cm}$ deep subsamples were taken by a spoon from different parts of the sediment surface in each case and mixed into a single sample stored in a vial containing a 70\% alcohol solution. Subsequently, a rose-bengal solution was added to stain the tissue of any living individuals. Mixing five random samples taken at a sampling site reduces the probable sampling error by $\sim 55 \%$ (Krumbein 1934). It also pays tribute to the fact that benthic forams inherently have a patchy distribution in the sediment (Buzas 1968; cf. also Buzas et al. 2015, for a comprehensive overview).

In the laboratory, the samples were washed through a set of two sieves having a 2-mm mesh at the coarse end and a 0.063$\mathrm{mm}$ mesh at the fine end (sand range). The residue was dried and, because it was predominantly composed of quartz grains, the forams were separated by flotation using tetrachloroethylene $\left(\mathrm{C}_{2} \mathrm{Cl}_{4}\right)$. The flotation procedure was carried out twice and the resulting foram concentrates assessed with respect to the frequency of the largest tests. This led to the decision of only analysing the $<0.25 \mathrm{~mm}$ size fraction because, in coarser size fractions, the number of foram tests was too low for meaningful statistical analysis (e.g. Lohmann 1978; Lutze 1980). The foram concentrates of each sample were weighed and then split down by microsplitter to a manageable number of at least 250 tests. The counted forams in each split were weighed in order to enable extrapolation of microfaunal concentration per sample (e.g. Scheder et al. 2019). For the identification of foram species, the first author made use of the resources and professional guidance available at the Marine Micropaleontology Research Group of the Institute of Geosciences, University of Kiel, Germany.

Regression analyses were applied to test the degree of correlation between the frequency of the two most abundant foram species and different sediment types. These were carried out by application of the software program TableCurve $2 \mathrm{D}^{\mathrm{TM}}$ of Systat Software Inc., San Jose, California.

\section{Results}

\section{Taxonomic aspects}

In the following, only those taxa are described which contributed more than $10 \%$ to the total fauna. In addition, two taxa are included that depart from the otherwise temperate faunal assemblage, even though their contribution lies below $10 \%$. The overall most abundant foram species are listed in Table 2 (in order of descending abundance). Together with some additional taxa, these are illustrated in Figs. 2 and 3. Missing from the list are Textularia pseudogramen and Textularia

Table 1 Water depths and geographic coordinates of samples selected for foraminiferal analysis

\begin{tabular}{|c|c|c|c|c|c|c|c|}
\hline \multirow{2}{*}{$\begin{array}{l}\text { Sample number } \\
148\end{array}$} & \multirow{2}{*}{$\begin{array}{l}\text { Water depth (m) } \\
47\end{array}$} & \multicolumn{2}{|c|}{$\begin{array}{l}\text { Geographic coordinates } \\
\text { latitude S longitude E }\end{array}$} & \multirow{2}{*}{$\begin{array}{l}\text { Sample number } \\
224\end{array}$} & \multirow{2}{*}{$\begin{array}{l}\text { Water depth (m) } \\
45\end{array}$} & \multicolumn{2}{|c|}{$\begin{array}{l}\text { Geographic coordinates } \\
\text { latitude S longitude E }\end{array}$} \\
\hline & & $34^{\circ} 06.9^{\prime}$ & $23^{\circ} 17.7^{\prime}$ & & & $34^{\circ} 05.9^{\prime} \mathrm{S}$ & $23^{\circ} 29.5^{\prime} \mathrm{S}$ \\
\hline 150 & 64 & $07.4^{\prime}$ & $17.8^{\prime}$ & 236 & 72 & $06.1^{\prime}$ & $32.0^{\prime}$ \\
\hline 151 & 69 & $08.5^{\prime}$ & $17.6^{\prime}$ & 240 & 68 & $03.9^{\prime}$ & $31.7^{\prime}$ \\
\hline 152 & 82 & $09.3^{\prime}$ & $17.6^{\prime}$ & 245 & 28 & $33^{\circ} 59.3^{\prime}$ & $34.3^{\prime}$ \\
\hline 154 & 93 & $11.2^{\prime}$ & $17.7^{\prime}$ & 248 & 52 & $34^{\circ} 00.5^{\prime}$ & $34.3^{\prime}$ \\
\hline 155 & 94 & $2.1^{\prime}$ & $17.7^{\prime}$ & 249 & 64 & $01.0^{\prime}$ & $34.2^{\prime}$ \\
\hline 159 & 91 & $08.9^{\prime}$ & $27.3^{\prime}$ & 250 & 71 & $01.8^{\prime}$ & $34.0^{\prime}$ \\
\hline 163 & 42 & $08.0^{\prime}$ & $27.2^{\prime}$ & 251 & 75 & $02.9^{\prime}$ & $34.2^{\prime}$ \\
\hline 165 & 37 & $06.9^{\prime}$ & $27.2^{\prime}$ & 253 & 76 & $05.1^{\prime}$ & $34.2^{\prime}$ \\
\hline 168 & 51 & $05.4^{\prime}$ & $27.4^{\prime}$ & 254 & 80 & $06.2^{\prime}$ & $34.3^{\prime}$ \\
\hline 170 & 52 & $04.0^{\prime}$ & $27.3^{\prime}$ & 255 & 86 & $07.4^{\prime}$ & $34.2^{\prime}$ \\
\hline 171 & 50 & $03.0^{\prime}$ & $27.2^{\prime}$ & 256 & 91 & $08.5^{\prime}$ & $34.2^{\prime}$ \\
\hline 174 & 38 & $01.6^{\prime}$ & $27.4^{\prime}$ & 266 & 37.5 & $03.4^{\prime}$ & $24.9^{\prime}$ \\
\hline 176 & 17 & $00.7^{\prime}$ & $27.2^{\prime}$ & 267 & 30 & $02.3^{\prime}$ & $24.3^{\prime}$ \\
\hline 180 & 17.5 & $02.4^{\prime}$ & $24.2^{\prime}$ & 292 & 86 & $09.5^{\prime}$ & $24.0^{\prime}$ \\
\hline 185 & 12 & $05.6^{\prime}$ & $24.0^{\prime}$ & 297 & 34 & $06.7^{\prime}$ & $22.2^{\prime}$ \\
\hline 198 & 97.5 & $09.4^{\prime}$ & $27.2^{\prime}$ & 306 & 65 & $08.2^{\prime}$ & $20.0^{\prime}$ \\
\hline 212 & 54 & $03.2^{\prime}$ & $28.4^{\prime}$ & & & & \\
\hline
\end{tabular}


Table 2 List of species (in decreasing number order) which overall exceeded $10 \%$ in all analysed samples combined, together with the year of first description, total number of tests and the number of dead and living tests, in each case

\begin{tabular}{|c|c|c|c|}
\hline Foraminifer species & $\begin{array}{l}\text { Total } \\
\text { counts }\end{array}$ & Dead tests & $\begin{array}{l}\text { Living } \\
\text { tests }\end{array}$ \\
\hline Bolivina cf. pseudopunctata Höglund (1947) & 2789 & 1862 & 927 \\
\hline Cassidulina laevigata d'Orbigny (1826) & 2080 & 1885 & 195 \\
\hline Bulimina elongata d'Orbigny var. subulata (1846) & 1055 & 719 & 336 \\
\hline Textularia conica (d'Orbigny) (1839) [incl. rare Textularia species] & 838 & 752 & 86 \\
\hline Cibicides lobatulus (Walker \& Jacob) (1798) & 690 & 656 & 34 \\
\hline Bolivina tortuosa Brady var. atlantica (Cushman) (1937) & 599 & 583 & 16 \\
\hline Cassidulina obtusa Williamson (1858) & 595 & 591 & 4 \\
\hline Ammonia beccarii (Linné) (1758) & 593 & 555 & 238 \\
\hline Pararotalia sp. (numerous species described from 1827-2001) & 516 & 504 & 12 \\
\hline Planorbulina mediterranensis d'Orbigny (1826) & 341 & 320 & 21 \\
\hline Discorbis australiensis (Heron-Allen \& Earland) (1932) & 17 & 17 & 0 \\
\hline \multirow[t]{2}{*}{ Chrysalidina dimorpha (Brady) (1881) } & 5 & 5 & 0 \\
\hline & 10318 & 8449 & 1869 \\
\hline
\end{tabular}

sagittula due to their overall low abundance, the Textularia group being represented in the list by Textularia conica, which is the overall fourth-most abundant foram in the study area. All three taxa are, however, illustrated (cf. Fig. 2) because together they form the dominant component in faunal assemblage A (see further down). Also not listed is Elphidium advenum (Cushman) because of its very low abundance. It is nevertheless illustrated (cf. Fig. 3) because it forms a subordinate component in faunal assemblages B and C (see further down). Descriptions generally follow the terminology recommended by Hottinger (2006). The individual species addressed below follow the sequence listed in Table 2 :

\section{Bolivina cf. pseudopunctata Höglund (Fig. 3, no. 9; Höglund 1947)}

With a total number of 2789 tests (1862 dead, 927 living), this species is the most abundant in the study area, at some stations contributing over $40 \%$. It is well illustrated in Höglund (1947), who placed them in a water depth range of preferentially 26-118 $\mathrm{m}$ in the Gulmarfjord, Skagerrak, Sweden. In the study area, it is commonly associated with Bolivina tortuosa and is most abundant in the depth range of 50-70 m, but is also found in shallower water where the sediment contains appreciable amounts of mud.

\section{Cassidulina laevigata d'Orbigny (Fig. 3, no. 14; d'Orbigny 1826)}

This species achieved a total abundance of 2080 tests (1885 dead, 195 living). It is well illustrated in Feyling-Hanssen (1964). In the study area, it is most abundant in samples from water depths exceeding $70 \mathrm{~m}$, where it may contribute up to $47 \%$ of the foram fauna. As opposed to the very similar species Cassidulina carinata (Silvestri), which occurs abundantly along the west coast of South Africa (Martin 1981), the Cassidulina species recorded in the study area does not have a pronounced 'carina'. On account of this, it was identified as C. laevigata.

\section{Bulimina elongata d'Orbigny var. subulata Cushman and Parker (Fig. 3, no. 12; d'Orbigny 1846)}

This species is represented by 1055 tests (719 dead, 336 living). It is well illustrated in Barker (1960), where it stems from a water depth of 630 fathoms $(\sim 1152 \mathrm{~m})$ to the west of Ireland. In the study area, it is found in almost all samples across the depth range from 12-97 $\mathrm{m}$ and can contribute up to $12 \%$ of the counted tests. A very similar species, Bulimina gibba, which is well represented along the west coast of South Africa (Martin 1981), was not found in the Plettenberg Bay samples.

\section{Textularia conica (d'Orbigny) (Fig. 2, no. 5; d'Orbigny 1839)}

Also pictured are Textularia pseudogramen (Chapman \& Parr) (Fig. 2, no.6) and Textularia sagittula Defrance (Fig. 2, no. 7). Good illustrations of the three species can be found in Norvang (1966), Lutze (1974) and Murray (1971), respectively. The total abundance of the three Textularia species combined amounts to 838 tests (752 dead, 86 living). During the identification procedure, it turned out that it was not always possible to clearly distinguish between the three species, as a result of which the counts were eventually pooled. They occur in the greatest abundance at water depths up to $50 \mathrm{~m}$, where on average, they contribute $20 \%$ to the fauna. $T$. conica was nevertheless the most frequent species, estimated to contribute on average up to $17 \%$. The group reaches its highest abundance $(>90 \%)$ in coarse-grained nearshore sands (mean diameter $>0.25 \mathrm{~mm}$ ). 
Fig. 2 Selection of the most frequent Foraminifera observed in the study area (group 1). 1Planorbulina mediterranensis d'Orbigny; a - umbilical side, b - spiral side; sample station (st) 176; water depth (wd) 17 m. 2Cibicides lobatulus (Walker \& Jacob); spiral side; st 297; wd 34 m. 3-Discorbis australiensis (Heron-Allen \& Earland); two articulated tests; a - spiral side; bumbilical side; st 224; wd 45 m. 4-Pararotalia sp.; a - spiral side; b - umbilical side; st 185; wd 12 m. 5-Textularia conica (d'Orbigny); oblique view; st 174; wd 38 m. 6-Textularia pseudogramen; oblique view; st 174; wd 38 m. 7-Textularia sagittula; st 174; wd $38 \mathrm{~m}$. For geographic positions of sample stations cf. Table 1

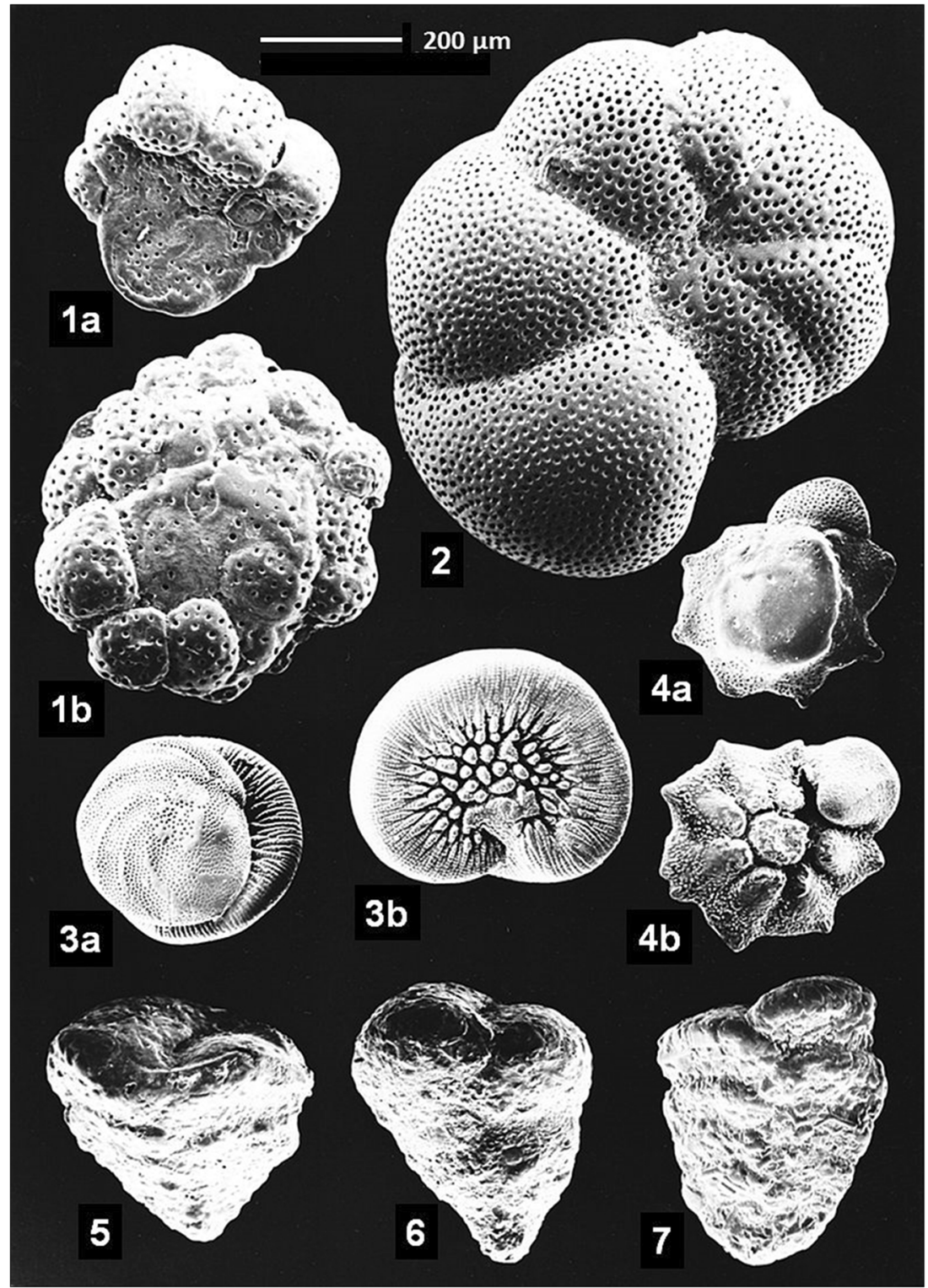

\section{Cibicides lobatulus (Walker \& Jacob) (Fig. 2, no. 2; Walker and Jacob 1798)}

Good illustrations can be found in Murray (1971). The total abundance of this grain-attached species amounts to 690 tests (656 dead, 34 living). It is found in almost all samples, but achieves its greatest abundance (14\%) in nearshore sediments with mean diameters coarser than $0.25 \mathrm{~mm}$.

\section{Bolivina tortuosa Brady var. atlantica (Cushman) (not pictured; Cushman 1937)}

The total abundance amounts to 599 tests (583 dead, 16 living). Good illustrations of this species can be found in Cushman (1937), the examples having been collected in shallow water $(\sim 20 \mathrm{~m})$ off the Cape Verde Islands. In departure from these cases, the individuals from the study area have a more elongated test, a larger number of chambers and a more lobulate outline. It is commonly associated with $B$. cf. pseudopunctata and is most abundant (up to 15\%) in samples from 30-70 m water depth.

\section{Cassidulina obtusa Williamson (Fig. 3, no. 13; Williamson 1858)}

Good illustrations can be found in Sejrup and Guilbault (1980) who rated it as an indicator species for temperate climatic conditions. The total abundance in the study area amounted to 595 tests (591 dead, 4 living). It was found in 22 of the analysed 35 samples, and reached maximum contributions of $15 \%$. Phleger and Parker (1951) found this species in the Gulf of Mexico with greatest abundances at water depths from 50-200 m. In the study area, it was found at water depths of $30-90 \mathrm{~m}$. 
Fig. 3 Selection of the most frequent Foraminifera observed in the study area (group 2). 8 Chrysalidina dimorpha (Brady); a- peripheral view; b-aperture side; st 165; wd 37 m. 9Bolivina cf. pseudopunctata Höglund; a, b, c note variability of test shape; st 170; wd 52 m. 10 Ammonia beccarii (Linné); aumbilical side; $b$ - peripheral view of aperture side; c - alt. umbilical side; $d$ - peripheral view; st 250; wd $71 \mathrm{~m} .11-$ Elphidium advenum (Cushman); spiral side; st 248; wd 52 m. 12 Bulimina elongata d'Orbigny; peripheral view; st 224; $45 \mathrm{~m}$. 13-Cassidulina obtusa

Williamson; umbilical side; st 255; wd 86 m, 14 -Cassidulina laevigata d'Orbigny; umbilical side; st 255; wd 86 m. For geographic positions of sample stations cf. Table 1

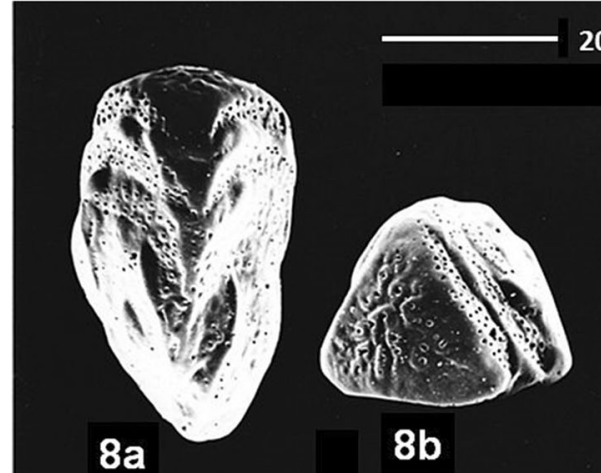

$200 \mu \mathrm{m}$

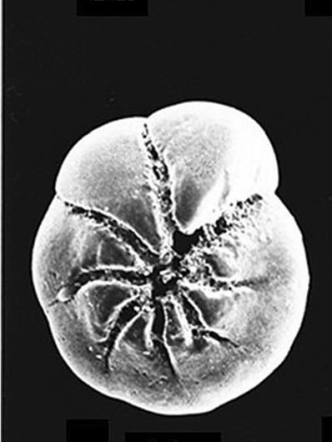

$10 \mathrm{a}$
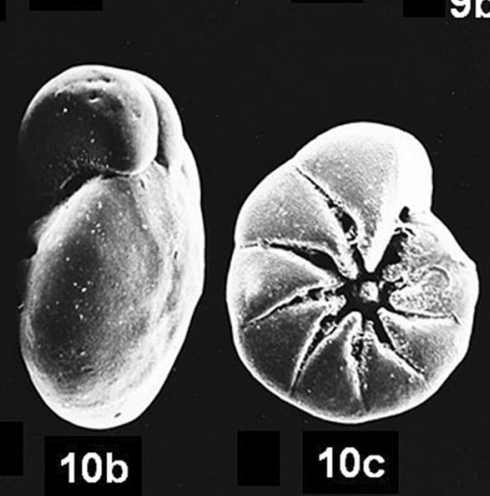

$10 \mathrm{c}$

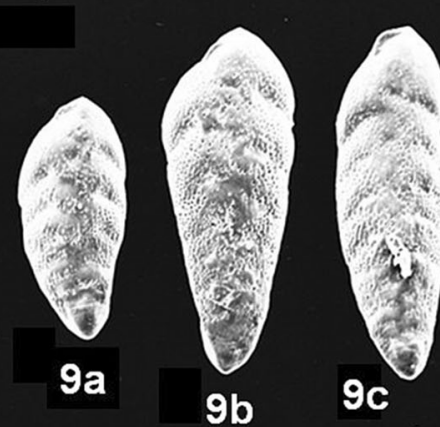

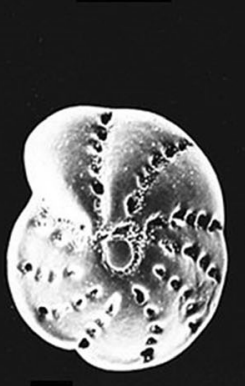

11

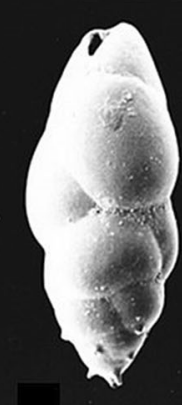

12

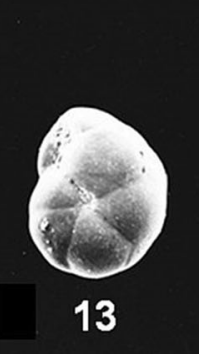

13

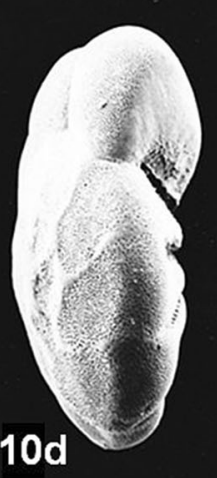

\section{Ammonia beccarii (Linné)/Rotalia beccarii Linné (Fig.} 3 , no. 10; Linné 1758)

This species is described and illustrated in Cushman (1931). It is a globally distributed shallow-water species (Murray 1971). The total abundance in the study area amounted to 593 tests (555 dead, 238 living). The test shapes of this species, which occurred in almost all samples from the study area, are rather variable. It reaches abundances of $20 \%$ of the total fauna but without showing any particular trend in its distribution.

\section{Pararotalia sp. (Fig. 2, no. 4; numerous species described from 1827-2001)}

The total abundance of this species in the study area amounted to 516 tests (504 dead, 12 living). It is quite common in nearshore sediments (18\%) where, together with the Textularia group, it may contribute up to $50 \%$ to the total fauna. It can be distinguished from $P$. cf. nipponica, which Martin (1981) has described from the South African west coast shelf, by the presence of spines and an overall rounder test shape.

\section{Planorbulina mediterranensis d'Orbigny (Fig. 2, no. 1; d'Orbigny 1826)}

This species is described and illustrated in Murray (1971) who recorded living examples from shallow waters $(10-60 \mathrm{~m})$ along the coast of England, where they are attached to algae and rocks. Because of this, grab samplers mostly recover dead tests in surrounding sediments. In the study area, its abundance amounted to 341 tests (320 dead, 21 living), being mostly restricted to water depths $<30 \mathrm{~m}$. 
Discorbis australiensis (Heron-Allen \& Earland) (Fig. 2, no. 3; Heron-Allen and Earland 1932)

The species is described and illustrated in Barker (1960). The total abundance in the study area amounted to only 17 dead tests, being mentioned here because it is a typical warm-water species common in the Indian and Pacific Oceans. Of particular interest in the present case is that 10 of the 17 recorded examples were found to be stuck together with their umbilical sides which, according to Grell (1968), could be a temporary position in the reproductive cycle. The species was identified in sample stations 148 (47 m), 159 (91 m), 165 (37 m), 168 (51 m), 185 (12 m), 224 $(45 \mathrm{~m})$ and $254(80 \mathrm{~m})$ (cf. Table 1$)$.

\section{Chrysalidina dimorpha (Brady) (Fig. 3, no. 8; Brady 1881)}

This species was first described by Brady (1881). According to Cushman (1911), it is a shallow warm-water species. It is very rare in the study area, its abundance amounting to only 5 dead tests. Despite its rare occurrence, it is mentioned here because it represents a warm-water species common in the Indian and Pacific Oceans. It was identified in the samples from stations 152 (82 m), 163 (42 m), 165 (37 m) and 236 (72 m) (cf. Table 1).

\section{Ecological aspects}

The analysis of foram abundances in the study area allowed the distinction between three distinct faunal assemblages (A, B and C). Foram assemblages are defined by the dominance of at least two, but frequently more, specific species (e.g. Lutze 1980). The identified assemblages are aligned in three consecutive, coastparallel belts, assemblage $\mathrm{A}$ forming the inshore belt, assemblage $\mathrm{C}$ the offshore belt and assemblage $\mathrm{B}$ the in-between belt (Fig. 4).

Assemblage A is dominated by tests of the Textulariagroup (with Textularia conica as the major representative), Pararotalia sp., Cibicides lobatulus and Planorbulina mediterranensis. This assemblage occupies the nearshore zone in water depths from $<12-50 \mathrm{~m}$. The sediments are composed of very fine, fine and medium sands, locally containing appreciable amounts of coarse and very coarse sands.

Next in line is assemblage B, which is composed of Bolivina cf. pseudopunctata, Cassidulina laevigata, Ammonia beccarii, Bolivina tortuosa, Bulimina elongata, (Cassidulina obtusa) and (Elphidium advenum). The species in brackets occur in low abundance. Assemblage B predominantly occupies water depths ranging from $50-70 \mathrm{~m}$, but locally extends down to $90 \mathrm{~m}$ (e.g. south of the Robberg spit-bar; cf. Fig. 1) and within the bay itself upward to $20 \mathrm{~m}$. The sediments are mainly composed of fine and very fine sands containing appreciable amounts of medium sand and mud. Although assemblage B has much in common with assemblage $\mathrm{C}$, it distinguishes itself from the latter by a distinctly higher abundance of B. cf. pseudopunctata ( 40\%).
Assemblage C, finally, is dominated by Cassidulina laevigata, Bolivina cf. pseudopunctata, Bulimina elongata, Ammonia beccarii, (Elphidium advenum) and (Bolivina tortuosa). The species in brackets occur in low abundance. In contrast to assemblage $\mathrm{B}$, assemblage $\mathrm{C}$ is dominated by $C$. laevigata which reaches abundances up to $47 \%$, whereas $B$. cf. pseudopunctata (which dominates assemblage B) barely reaches $15 \%$. Assemblage $\mathrm{C}$ is mainly confined to water depths of 70-100 $\mathrm{m}$ in sediments dominated by very fine sand $(0.063$ $0.125 \mathrm{~mm}$ ) containing appreciable amounts of both coarser (fine-medium) sand and mud.

\section{Environmental aspects}

\section{Water depth}

The belt-like, coast-parallel arrangement of the individual foram assemblages (Fig. 4) could, at first sight, be interpreted as indicating that water depth could be a major factor controlling their distribution (e.g. Martin 1981). However, a closer look reveals that there are considerable depth overlaps between them. Thus, assemblage A reaches down to $75 \mathrm{~m}$ in the north-eastern part of the study area, while assemblage B encroaches on assemblage A within the bay up to a depth of 20 $\mathrm{m}$. Similarly, assemblage $\mathrm{C}$ extends down to $70 \mathrm{~m}$ in the western part of the study area, while assemblage B extends down to $>90 \mathrm{~m}$ just south of the Robberg spit-bar. These depth overlaps argue against a strictly depth-controlled distribution (cf. Funnell 1967; van der Zwaan 1999) and, instead, suggest that water depth is merely a proxy for a variety of ecofactors (e.g. turbulence, grain size, sediment sorting, organic matter) which, in dependence of the local environmental conditions, determine the distribution of individual foram assemblages.

\section{Sediment composition}

As in the case of water depth, a comparison of the distribution pattern of the three faunal assemblages with those of individual grain-size fractions (Flemming, unpublished) can be interpreted to argue in favour of control by grain size, or rather sediment composition. Such a relationship has, for example, been observed by Lutze and Coulbourn (1984). As narrated in the ecological section, each assemblage is clearly associated with particular grain-size ranges, although considerable overlaps are also evident here. To test this, the abundance (frequency-\%) of six common foram species in the study area was plotted against water depth (Fig. 5a). Again, at first sight, the pattern appears to favour water depth as the main control factor, the frequencies of B. cf. pseudopunctata, C. laevigata, A. beccarii and $B$. elongata dominating the diagram in water depths greater $\sim 45 \mathrm{~m}$. Together, they reach frequencies of almost $75 \%$, whereas Pararotalia sp. and the Textularia-group forams dominate the depth range above $45 \mathrm{~m}$. However, the fact that both the mud and 


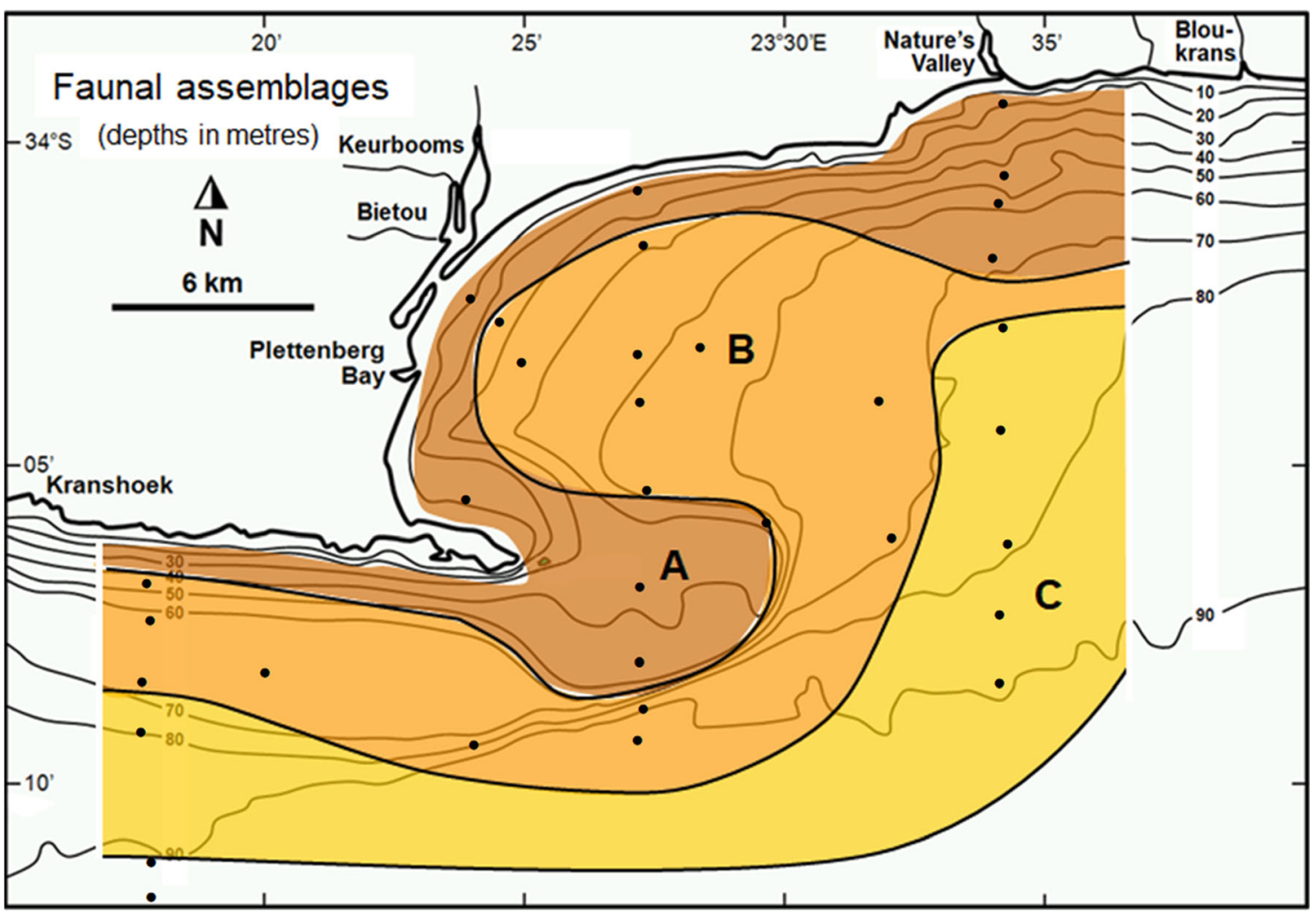

Fig. 4 Distribution of the three identified foram assemblages (A, B, C) on the coastal shelf of Plettenberg Bay

very fine sand contents of the sediment are also restricted to water depths $>45 \mathrm{~m}$ (Figs $5 \mathrm{~b}, \mathrm{c}$ ) challenges the water depth hypothesis because the deeper-water foram group could just as well be associated with these sediment types. Incidentally, Fig. 5a also reveals that the depth distributions of $B$. cf. pseudopunctata and $C$. laevigata show an inverse pattern. The former dominates the depth range from $50-70 \mathrm{~m}$, which is characterized by greater mud (up to $35 \%$ ) and lower very fine sand (up to $40 \%$ ) contents. The latter, by contrast, dominates the depth range $>70 \mathrm{~m}$, which is characterized by lower mud (on average 10\%) and greater very fine sand (up to 60\%) contents. The water depth/sediment type characteristics, therefore, lead to an impasse in the decision which of the two potential control factors should be favoured. It would instead argue in favour of control by a combination of various environmental factors (e.g. van der Zwaan et al. 1999).

To test this hypothesis, the relation of the two most dominant species, $B$. cf. pseudopunctata and C. laevigata, with particular grain-size fractions was investigated (Fig. 6). The scatter plots of frequency vs grain-size fractions for $B$. cf. pseudopunctata, (Fig. $6 \mathrm{a}, \mathrm{b}, \mathrm{c}$ ) show that the correlations for this species are all positive, albeit with greatly varying coefficients. Thus, the coefficient of determination $\left(r^{2}\right)$ is 0.425 for mud (Fig. 6a), 0.036 for very fine sand (Fig. 6b) and 0.25 for fine+medium sand (Fig. 6c). This means that the regressions explain $42.5 \%$ of the variation in the case of mud, $25 \%$ of the variation in the case of fine+medium sand and only $3.6 \%$ of the variation in the case of very fine sand. This suggests that $B$. cf. pseudopunctata prefers muddy fine- medium sands, while tolerating some very fine sand. The relation between the faunal frequency and sediment type suggests that sediment type has, in this case, a slightly smaller influence on the distribution than do other water depth-related ecofactors.

In the case of $C$. laevigata, the scatter plots show positive correlations with mud and very fine sand (Fig. 6d, e), but a negative correlation with fine+medium sand (Fig. 6f). In contrast to $B$. cf. pseudopunctata, the coefficients of determination for $C$. laevigata explain 59\% of the variation for very fine sand (Fig. 6e) but only $11.8 \%$ for mud (Fig. 6d), while $51 \%$ of the variation is negative for fine+medium sand (Fig. 6f). This species thus clearly prefers a very fine sand substrate containing appreciable amounts of fine+medium sand and small amounts of mud. In this case, substrate has the edge over water depth. Taken together, the result of this frequency vs substrate analysis therefore supports the hypothesis that a combination of water depth-related ecofactors, in particular substrate type, most likely controls the distribution of the three foram assemblages.

\section{Water temperature}

The regional sampling campaign was carried out in late summer (March) of 1982. During sampling, the substrate temperature was measured as soon as the bucket was detached from the grab on deck. The range of temperatures for the Plettenberg Bay samples is illustrated in Fig. 7b. It reveals 
Fig. 5 Frequency of selected Foraminifera as a function of awater depth, $\mathrm{b}$ - mud content and $\mathrm{c}$ - very fine sand content

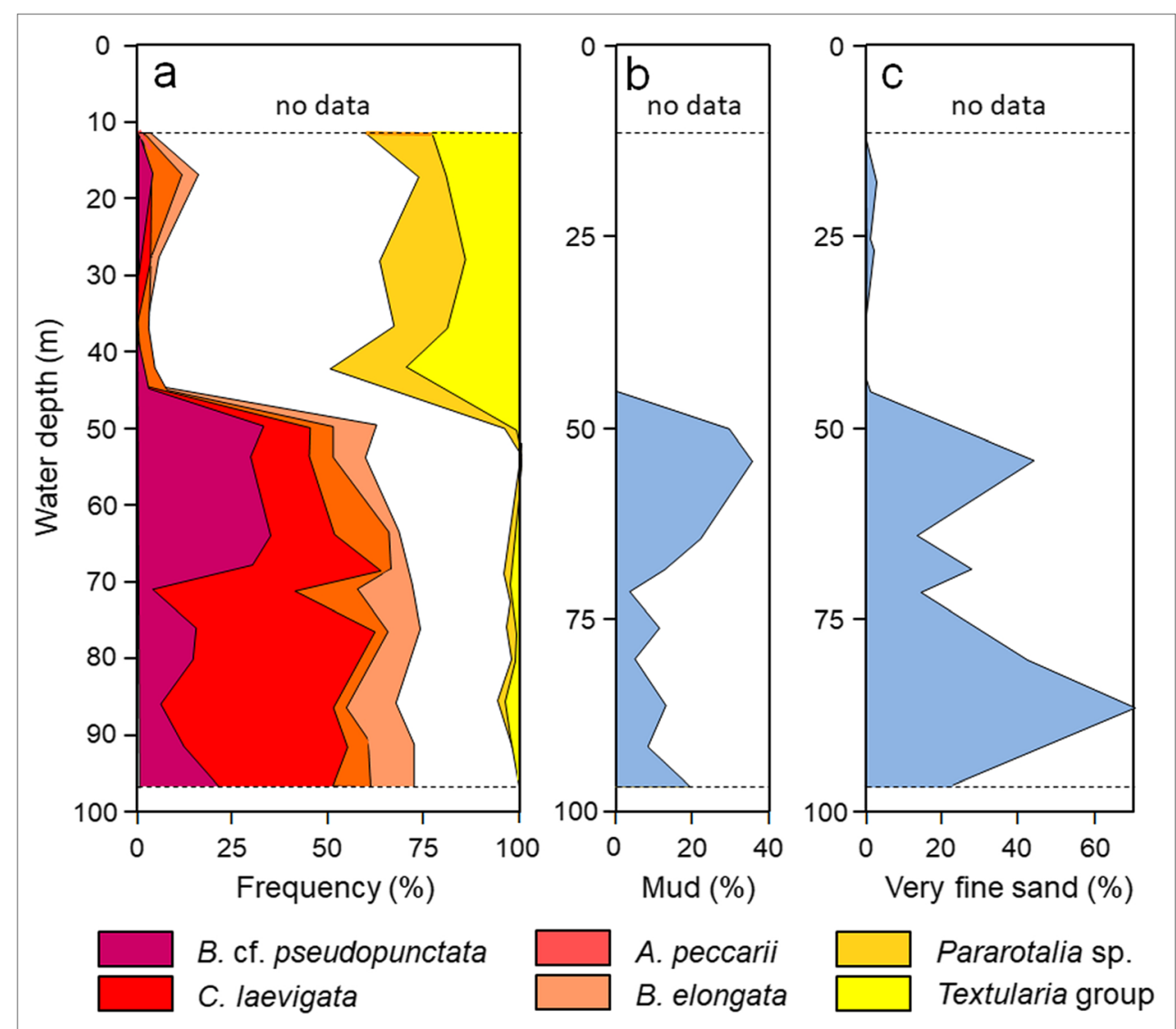

an almost homogenous temperature distribution across all water depths down to $100 \mathrm{~m}$, ranging between 10 and $14^{\circ} \mathrm{C}$. If this temperature structure was representative for longer time periods, then it would not speak in favour for water temperature being an additional control factor for the distribution of the forams in the study area. This notion is supported by the extremely rare occurrence of warm-water species in the study area. A temperature influence on the vertical distribution of forams has, for example, been postulated by Drobne and Cimerman (1984), but such a strict temperature control has subsequently been questioned by Van der Zwaan et al. (1999).

However, in comparison to Plettenberg Bay, the seabed temperatures in Mossel Bay, which is located about $100 \mathrm{~km}$ farther west, show a vertical structure compatible with the existence of a thermocline at 45-50 m (Fig. 7a). Below 50 $\mathrm{m}$, the temperatures are comparable to those in the Plettenberg Bay area; above $50 \mathrm{~m}$, they progressively increase with decreasing water depth to reach $\sim 21^{\circ} \mathrm{C}$ at the surface close to the coast. Warm surface waters originating from the Agulhas Current thus characterized the Mossel Bay but not the Plettenbarg Bay region at the time of sampling. Whether it plays an additional role in controlling the distribution of the foram assemblages thus depends on how temporally persistent the observed vertical thermal structure in Plettenberg Bay is.

\section{Discussion}

The forams of the Plettenberg Bay shelf area are mainly composed of species that are typical representatives of temperate climatic conditions (Boltovskoy and Wright 1976). Only two species, Discorbis australiensis (Heron-Allen \& Earland) and Chrysalidina dimorpha (Brady), represent warm-water faunas with affinity to the Indian Ocean (Barker 1960; Cushman 1911). The two warm-water species document that filaments (or eddies) of the warm Agulhas Current, which hugs the shelf edge of the Agulhas Bank far to the south, occasionally find their way to the innermost south coast shelf (Lutjeharms 2006), thereby carrying the two species into the study area. The fact that their abundance is extremely low suggests that, in the study area, this appears to happen only very episodically. However, it can be expected that their abundance increases towards the east and south i.e. towards the warm waters of the Agulhas Current, and possibly also in the shallow parts of the Mossel Bay region. It is presently unknown whether warmer nearshore waters are a characteristic feature of the latter region in the long-term. This question could possibly be answered by an analysis of the extant forams of that region because, in the event, it should reveal a greater proportion of warm-water species. 
Fig. 6 Correlations of the frequency of Bolivina $\mathrm{cf}$. pseudopunctata $(\mathbf{a}-\mathbf{c})$ and Cassidulina laevigata $(\mathbf{d}-\mathbf{f})$ with the contents of mud (a, d), very fine sand $(\mathbf{b}, \mathbf{e})$ and fine+medium sand $(\mathbf{c}, \mathbf{f})$ respectively
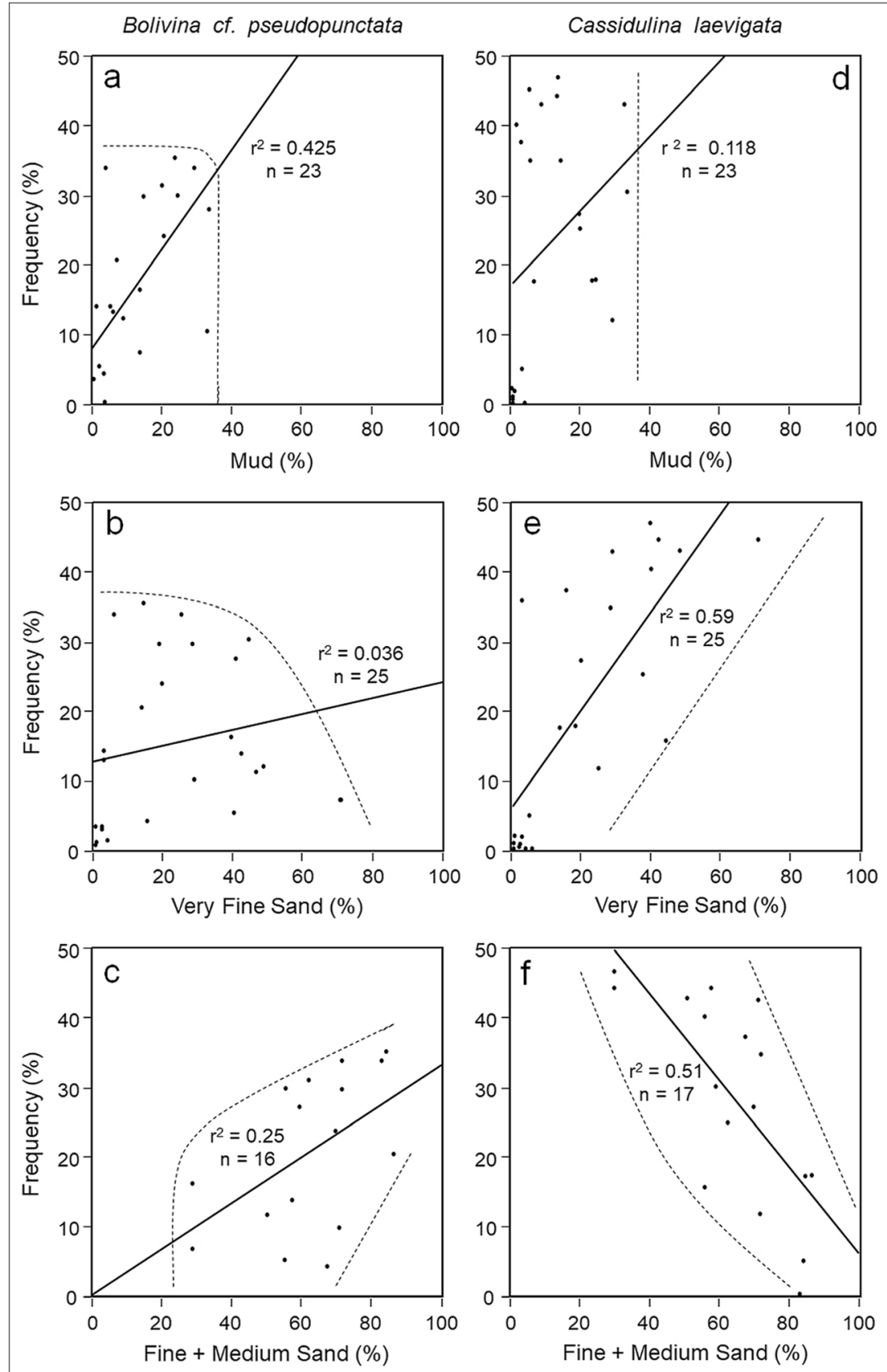

As in the case of other marine faunas, the identification of two warm-water species also emphasizes that the Agulhas Bank is a transitional area between the warm waters of the Indian Ocean and the temperate (upwelling) waters of the Benguela Current of the SE Atlantic. The evidence for a spatially differential influx of warm Agulhas Current waters at the time of the study raises the question whether the temperature structure characterized by a well-defined thermocline at a water depth of about $50 \mathrm{~m}$, as recorded by Schumann and Beekman (1984), actually reflects the long-term situation on the entire Agulhas Bank, or whether it is less consistent for the nearshore region (Largier and Swart 1987). It would thus be an instructive exercise to analyse the foram content of samples collected in the Mossel Bay area and nearer to the shelf break opposite the path of the Agulhas Current, in expectation that the variety and abundance of warm-water species should be more prominent in these areas.

When comparing the foram community in the study area with that of the nearby Knysna Lagoon (Strachan et al. 2016), the following differences and similarities emerged: of the 15 species recorded on a vegetated intertidal flat in Knysna Lagoon, only two species occur in both environments. One is Cibicides lobatulus, which occurs in very low numbers in the lagoon but is the 5 th most common species on the inner 
Fig. 7 Seabed temperature as a function of water depth: a Mossel Bay; b Plettenberg Bay. The two areas lie about $100 \mathrm{~km}$ apart. Both data sets were collected in the same month (March 1982; cf. Schumann et al. 1982)

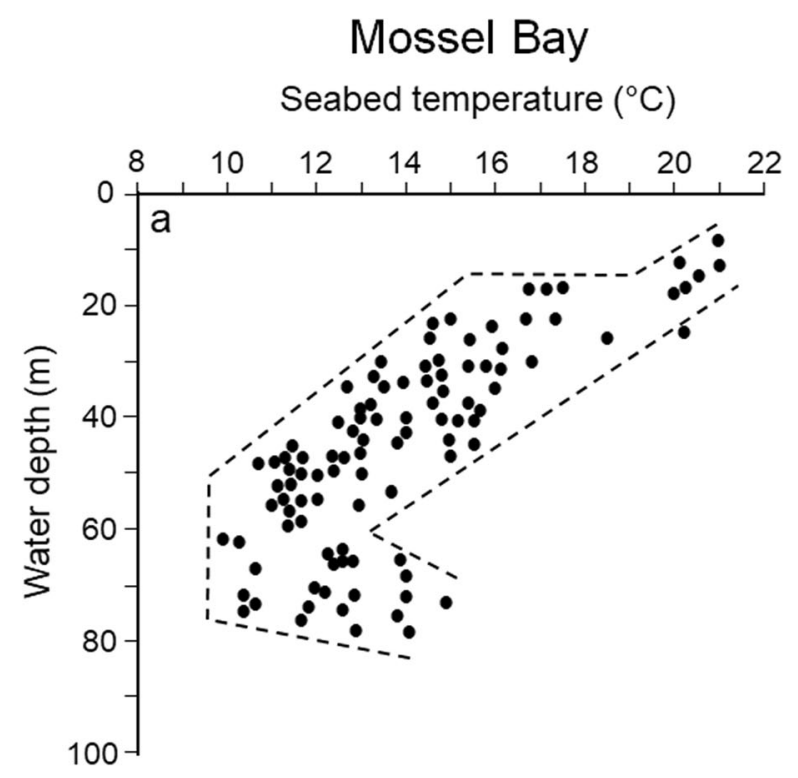

Mossel Bay

Plettenberg Bay Seabed temperature $\left({ }^{\circ} \mathrm{C}\right)$

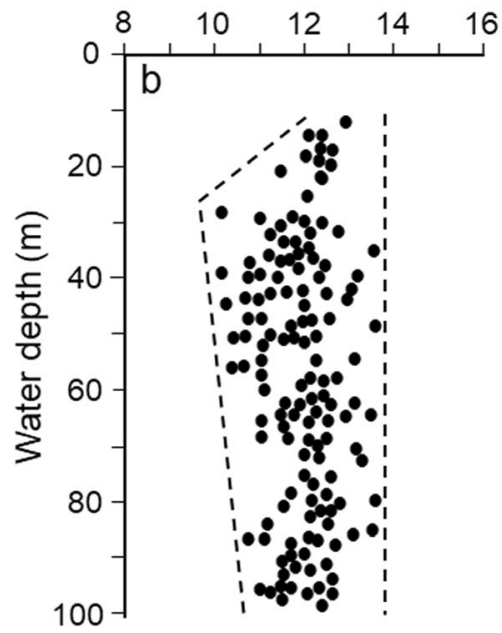

coastal shelf $<50 \mathrm{~m}$ water depth, the other is Elphidium sp., which occurs in low abundance in both environments, but is restricted to water depths $>50 \mathrm{~m}$ in the present study area. The comparison thus results in a surprisingly clear verdict, namely, that the foram communities of the two environments have very little in common. This also applies to the west coast, where the findings of Franceschini et al. (2005) in Langebaan Lagoon lead to the same conclusion.

\section{Conclusions and recommendations}

From the results of this study, the following conclusions can be drawn and recommendations be suggested:

The vast majority of forams in the study area belong to the temperate oceanic climate regime that is characteristic of the south-eastern South Atlantic; although rare, the two warm-water species linked to the subtropical Indian Ocean climate regime nevertheless confirm that the Agulhas Bank is a transitional environment between the temperate SE Atlantic and warm SW Indian oceans; the forams in the study area can be grouped into three faunal assemblages that are aligned in consecutive coast-parallel belts; the distribution of the forams in the study area in terms of water depth and sediment composition suggests that it is mainly controlled by ecofactors associated with these two parameters; evidently, no tangible relationship exists between nearshore foram communities and those of estuaries and lagoons along the South African coast; spatially selected nearshore surveys of foram faunas along the South African south coast should be carried out to establish the occurrence and spatial distribution of warm-water species.
Acknowledgements The study was carried out as part of the Agulhas Bank Studies programme of the National Research Institute for Oceanology (CSIR), Stellenbosch, South Africa. The authors gratefully acknowledge the assistance of AH Fricke $(\dagger)$, GFP Rule and W Akkers during the sample collection at sea. The Master and crew of the RV 'Meiring Naudé' are thanked for their diligent navigation and safe overside equipment handling. Prof. Dr. G. F. Lutze, Kiel University, Germany, is thanked for his professional supervision of foram identification and their ecological and environmental affinities.

Funding Open Access funding enabled and organized by Projekt DEAL.

\section{Declarations}

Competing interests The authors declare no competing interests.

Open Access This article is licensed under a Creative Commons Attribution 4.0 International License, which permits use, sharing, adaptation, distribution and reproduction in any medium or format, as long as you give appropriate credit to the original author(s) and the source, provide a link to the Creative Commons licence, and indicate if changes were made. The images or other third party material in this article are included in the article's Creative Commons licence, unless indicated otherwise in a credit line to the material. If material is not included in the article's Creative Commons licence and your intended use is not permitted by statutory regulation or exceeds the permitted use, you will need to obtain permission directly from the copyright holder. To view a copy of this licence, visit http://creativecommons.org/licenses/by/4.0/.

\section{References}

Barker RW (1960) Taxonomic notes on the species figured by H.B. Brady. SEPM Spec Publ 9:1-238

Boltovskoy E, Wright R (1976) Recent Foraminifera. Junk, The Hague $515 \mathrm{pp}$

Brady HB (1881) Notes on some of the Reticularian Rhizopoda of the "Challenger" Expedition. Part III. Quart J Microscop Sci 21(81):3171 
Branch M, Branch G (1981) The living shores of Southern Africa. Struik Publ, Cape Town

Buzas MA (1968) On the spatial distribution of Foraminifera. Contr Cushman Found Foram Res 19:1-11

Buzas MA, Hayek L-AC, Jett JA, Reed SA (2015) Pulsating patches history and analyses of spatial, seasonal, and yearly distribution of living benthic Foraminifera. Smithsonian Contr Paleobiol 97, 91 pp

Cawthra HC, Cowling RM, Ando S, Marean CW (2020) Geological and soil map of the Palaeo-Agulhas Plain for the last glacial maximum. Quat Sci Rev 235:105858. https://doi.org/10.1016/j.quascirev.2019. 07.040

Cooper JAG, McMillan IK (1987) Foraminifera of the Mgeni estuary, Durban, and their sedimentological significance. S Afr J Geol 90: 489-498

Cushman JA (1911) A monograph of the Foraminifera of the North Pacific Ocean. Part II. Textulariidae. Bull US Nat Mus 71(2):1-108

Cushman JA (1931) The Foraminifera of the Atlantic Ocean, Part 8. US Nat Mus Bull 104:1-179

Cushman JA (1937) A monograph of the subfamily Virgulinina of the foraminiferal family Buliminidae. Cushman Laboratory of Foraminiferal Research, Spec Publ 9:1-128

d'Orbigny AD (1826) Tableau méthodique de la classe des Céphalopodes. Annales des Sciences Naturelles 7(96-169):245314

d'Orbigny AD (1839) Foraminifères. In: de la Sagra R (ed) Histoire physique, politique et naturelle de l'ile de Cuba. Arthus Bertrand, Paris

d'Orbigny AD (1846) Foraminifères fossiles du bassin tertiaire de Vienne. Gide et Cie, Paris

Dingle RV, Rogers J (1972) Pleistocene palaeogeography of the Agulhas Bank. Trans Roy Soc S Afr 40:155-165

Drobne K, Cimerman NF (1984) Die vertikale Verbreitung der Lituolaceen und Miliolaceen (Foraminifera) an einem Unterwasserkliff in der Adria (Jugoslawien). Facies 11:157-172

Feyling-Hanssen RW (1964) Foraminifera in late Quaternary deposits from the Oslofjord area. Norges Geoliske Unders 225:1-383

Franceschini G, McMillan IK, Compton JS (2005) Foraminifera of Langebaan Lagoon salt marsh and their application to the interpretation of late Pleistocene depositional environments at Monwabisi, False Bay coast, South Africa. S Afr J Geol 108:285-296

Funnell BM (1967) Foraminifera in late Quaternary deposits from the Oslofjord area. Nor Geol Unders 5:333-347

Fürstenberg S, Gründler N, Meschner S, Frenzel P (2017) Microfossils in surface sediments of brakish waters on the west coast of South African and their palaeoecological implications. Afr J Aquat Sci 42:329-339

Grell KG (1968) Protozoologie. Springer Verlag, Berlin

Griffiths CL, Robinson TB, Lange L, Mead A (2010) Marine biodiversity in South Africa: an evaluation of current states of knowledge. PLoS ONE 5(8):e12008

Hempel S (1985) Zur Verbreitung rezenter benthischer Foraminiferen auf dem südlichen südafrikanischen Schelf. Msc thesis, University of Kiel, Germany

Heron-Allen E, Earland A (1915) The Foraminifera of the Kerimba Archipelago (Portuguese East Africa) -Part II. Trans Zool Soc London 20(17):543-794

Heron-Allen E, Earland A (1932) Some new Foraminifera from the South Atlantic. IV. Four new genera from South Georgia. J Roy Microscop Soc 52:253-261

Höglund H (1947) Foraminifera in the Gulmar Fjord and the Skagerrak. Zoolog bidr från Uppsala 26:1-328

Hottinger L (2006) Illustrated glossary of terms used in foraminiferal research. Carnets de Géologie/Notebooks on Geology Memoir 2006/02

Krumbein WC (1934) The probable error of sampling for mechanical analysis. Am J Sci 27:204-214
Largier JL, Swart VP (1987) East-west variation in thermocline breakdown on the Agulhas Bank. S Afr J Mar Sci 5:263-272

Linné C (1758) Systema naturæ per regna tria naturæ, secundum classes, ordines, genera, species, cum characteribus, differentiis, synonymis, locis. Tomus I. Editio decima, reformata. Laurentii Salvii, Holmiæ, Stockholm

Lohmann GP (1978) Abyssal benthonic foraminifers as hydrographic indicators in the western South Atlantic Ocean. Foram Res 8:6-34

Lutjeharms JRE (2006) The Agulhas Current. Springer-Verlag, Heidelberg

Lutze GF (1974) Benthische Foraminiferen in Oberflächensedimenten des Persischen Golfes, Teil 1: Arbeiten. 'Meteor'-Forsch-Ergebn C 17:1-66

Lutze GF (1980) Depth distribution of benthic Foraminifera on the continental margin off NW-Africa. 'Meteor'-Forsch-Ergebn C 32:3180

Lutze G, Coulbourn W (1984) Recent benthic foraminifera from the continental margin off northwest Africa: community structure and distribution. Mar Micropal 8:361-401

Martin RA (1974) Benthonic Foraminifera from the western coast of southern Africa. Joint Geological Survey/University of Cape Town Marine Geoscience Unit, Technical Report No 6:83-87

Martin RA (1981) Benthic Foraminifera from the Orange-Lüderitz shelf, southern African continental shelf. Joint Geological Survey/ University of Cape Town Marine Geoscience Unit, Bulletin No $11,75 \mathrm{pp}$

McMillan IK (1974) Recent and relict Foraminifera from the Agulhas Bank, South African continental margin. MSc thesis, University College of Wales, Aberystwyth

McMillan IK (1987) The genus Ammonia Brunnich, 1771 (Foraminiferida) and its potential for elucidating the latest Cainozoic stratigraphy of South Africa. S Afr J Sci 83:32-42

McMillan IK (1993) Foraminiferal biostratigraphy, sequence stratigraphy and interpreted chronostratigraphy of marine Quaternary sedimentation on the South African continental shelf. S Afr J Sci 89:83-89

Murray JW (1971) An Atlas of British Recent Foraminiferids. Heinemann Educational Books Ltd, London

Norvang A (1966) Textilina nov. gen., Textularia Defrance and Spiroplectammina Cushman, (Foraminifera). Biol Skr 15(3):1-6

Phleger FB, Parker FL (1951) Ecology of foraminifera, northwest Gulf of Mexico. Part II. Foraminifera species. Geol Soc Am Memoir 46:164

Scheder J, Frenzel P, Bungenstock F, Engel M, Brückner H, Pint A (2019) Vertical and lateral distribution of Foraminifera and Ostracoda in the East Frisian Wadden Sea - developing a transfer function for relative sea-level change. Geol Belgica 22:99-110

Schmidt-Sinns J (2008) Rezente benthische Foraminiferen im Bereich des Begulastroms, Südwestafrika - Verbreitungsmuster und ihre steuernden Faktoren. Doctoral dissertation, University of Bonn, Germany

Schumann EH, Beekman LJ (1984) Ocean temperature structure on the Agulhas Bank. Trans Roy Soc S Afr 45:191-203

Schumann EH, Flemming BW, Swart VP, Hunter IT (1982) Agulhas Bank Studies Report No. 8: Report on measurement programmes 20 January to 22 March 1982. NRIO (CSIR) Memorandum 8232, $39 \mathrm{pp}$

Sejrup HP, Guilbault JP (1980) Cassidulina reniforme and C. obtusa (Foraminifera), taxonomy, distribution and ecology. Sarsia 65:7985

Smit AJ, Bolton JJ, Anderson RJ (2017) Seaweeds in two oceans: betadiversity. Front Mar Sci 4, article 404

Strachan KL, Hill TR, Finch JM, Barnett RL (2015) Vertical zonation of foraminifera assemblages in Galpins salt marsh, South Africa. J Foram Res 45:29-41

Strachan KL, Finch JM, Hill TR, Barnett RL, Morris CD, Frenzel P (2016) Environmental controls of the distribution of salt-marsh 
foraminifera from the southern coastline of South Africa. J Biogeogr 43:887-898

Strachan KL, Hill TR, Finch JM (2017) Vertical distribution of living mangrove foraminfera from KwaZulu-Natal, South Africa. Afr J Mar Sci 39:409-422

Toefy R (2010) Extant benthic Foraminifera from two bays along the SW coast of South Africa, with a comment about their use as indicators of pollution. PhD thesis, University of Cape Town, Cape Town, South Africa

Toefy R, McMillan IK, Gibbons MJ (2003) The effect of wave exposure on the foraminifera of Gelidium pristoides. J Mar Biol Assoc UK 83: 705-710

Toefy R, Gibbons MJ, McMillan IK (2005) The foraminifera associated with the alga Gelidium pristoides, South Africa. Afr Invertebr 46:126
Van der Zwaan GJ, Duijnstee IAP, den Dulk M, Ernst SR, Jannik NT, Kouwenhoven TJ (1999) Benthic foraminifers: proxies or problems? A review of paleo-ecological concepts. Earth-Sci Rev 46: 213-236

Walker G, Jacob E (1798) mentioned in Kanmacher F (1798) Adams' Essays on the Microscope, 2nd Edition. Dillon and Keating, London

Williamson WC (1858) On the recent Foraminifera of Great Britain. The Ray Society, London $107 \mathrm{pp}$

Wright CI, McMillan IK, Mason TR (1990) Foraminifera and sedimentation patterns in St. Lucia Estuary mouth, Zululand, South Africa. S Afr J Geol 93:592-601

Publisher's note Springer Nature remains neutral with regard to jurisdictional claims in published maps and institutional affiliations. 